\title{
An Evaluation of the Speech Acts Used in Sermons from Selected Pentecostal Churches in Eldoret Town, Kenya
}

\author{
Monica Oloo Oluoch \\ Lecturer, Department of Languages and Literature, Africa Nazarene University, \\ PO Box 53067-00200, Nairobi, Kenya
}

\begin{abstract}
This paper analyses communication in pulpit discourse by examining the speech acts used in sermons from selected Pentecostal churches in Eldoret town, Kenya. Specifically, this paper discusses how preachers use speech acts in their sermons to convey specific meaning. The paper is informed by the Speech Acts theory and the Cooperative Principle. The data was collected through camcorder video recording and participant observation. The data from the camcorder was transcribed word-for-word and then analysed at the level of speech acts. The relevant texts were extracted from the selected sermons to illustrate the speech acts identified. The linguistic and non-linguistic cues that trigger the speech acts were also identified. The study revealed that the preachers make assertions and affirmations and that they also warn, challenge and advise the audience in a bid to transform their lives. From the results, it was shown that preachers perform different speech acts using different clause types. These speech acts were categorised into constantives, directives, commissives and acknowledgements. It is recommended that future research should focus on the use of idioms in sermons to examine their relevance for communication. The study analysed sermons from Pentecostal churches in town only and the researcher would recommend that the same concepts be analysed in sermons from Pentecostal churches in the rural area.
\end{abstract}

Keywords: Speech acts, Sermons, Pentecostal, Eldoret town, Kenya

DOI: $10.7176 / J L L L / 69-07$

Publication date:June 30th 2020

\section{Introduction}

This paper is situated within studies on aspects of communication in pulpit discourse, specifically on speech acts and implicatures used by preachers to convey their intentions. Communication comes from the Latin word, communicare, which means, "to make common". Pearson and Nelson (1994) define communication as the "process of understanding and sharing meaning" (p. 6). They further define public communication as "the process of understanding and sharing meaning with a number of other people when one person is generally identified as the source (speaker) and others are recognized as receivers (listeners)" (p. 6). Pulpit discourse, which refers to sermons in this study, takes place in the public setting of the church where the preacher is the source and the members of the congregation are the receivers, hereinafter referred to as the audience. The preacher thus shares meaning with the audience via the speech event which is the sermon. A sermon is a kind of discourse that appears like a monologue but still employs some strategies to ensure audience participation. Sermons are messages delivered by speakers vested with some spiritual authority within the church or any gathering of Christians.

Trenholm (2001) says that "although audience members may ask questions afterwards, their major role during the speech is to listen to and evaluate what the speaker has to say" (p. 258). This is generally true of sermons because the audience does not have a chance to ask questions during the sermon. The preacher controls the discourse and the situation places constraints on the co-interactants to listen while he speaks. In Pentecostal churches, however, the preachers attempt to involve the audience by asking questions or eliciting response in different ways. Due to this involvement of the audience by the preachers, Pentecostal preaching is often characterized by active listener response.

According to Pearson and Nelson (1994), "public communication most often has the purpose of informing or persuading, but it can also have the intent of entertaining, introducing, announcing, welcoming or paying tribute" (p. 18-19). This applies to this paper because in identifying the speech acts used in sermons the researcher was in fact establishing the intentions of the preacher in the utterances made. Preachers do not just speak for the sake of it but they have intentions they endeavour to convey through their utterances. This is supported by Trenholm (2001) who says:

People seldom make sentences just to show off grammatical knowledge. We talk to accomplish goals. Pragmatic knowledge allows us to understand the intentions of others and to make our own intentions clear. The goal a speaker intends to accomplish is called a speech act. Successful communication involves understanding the relationship between words and sentences and the speech acts they represent. To do this, we have to go beyond grammatical knowledge and draw on social knowledge (p. 80).

An examination of speech acts goes beyond semantic understanding since it seeks to identify the intentions of speakers in making certain utterances. Pragmatics provides a bridge between what is literally expressed and what is actually said and understood. When a preacher makes an utterance such as "If you want to give your life to 
the Lord, raise up your hand and I will pray for you," he has the intention of getting the listener to respond in a certain way. Semantically, the utterance means the audience has a choice to make on what to do with their life. Based on their context, which is preaching, and the shared knowledge of the audience that preachers aim at winning people to God, the speech act performed by this utterance is inviting those who want to get saved to do so. The preacher performs two acts by this utterance: Inviting and promising. This interpretation goes beyond the semantic meaning of the words because the context is considered in arriving at the meaning. The context gives us the social information needed to understand the speech acts.

Speech acts are the social functions performed by utterances, for example asserting, promising, questioning, advising and warning. A speech act is created when a speaker/writer $S$ makes an utterance $U$ to a hearer/reader $H$ in context $C$. The illocutionary force of $U$ is what $S$ does in $Y$, for example states or requests something, thanks someone, makes a promise, declares an umpiring decision etc. (Asher \& Simpson, 1994, p. 4124). Every speech act conveys at least one illocutionary force, most convey more than one. Labov and Fanshel (1977, as cited in Asher \& Simpson, 1994), say that "speech acts are a part of social interactive behaviour and must be interpreted as an aspect of social interaction" (p. 30). This approach is relevant to this paper because the church service is seen as a social event where people who share certain beliefs in common meet to interact. The interpretation of speech acts is based on the setting of the speech event: preaching.

\subsection{Literature Review}

The Greek philosopher, Aristotle, saw the function of rhetoric as the discovery of "available means of persuasion" and according to him, the available means of persuasion are based on three kinds of proof: logical (logos), ethical (ethos) and emotional (pathos) (Griffin, 2000). Logical proof comes from the line of argument in the speech, ethical proof is the way the speaker's character is revealed through the message, and emotional proof is the feeling the speech draws out of the hearers (Griffin, 2000, p. 276).

These three bases of the available means of persuasion are relevant to the study because the speakers employ all the means of persuasion at their disposal in order to achieve the desired effect. The speech acts used by the preachers are aimed at appealing to the audiences logically, ethically and emotionally. In sermons, the speaker's character is very crucial since the speaker needs to appeal to the audience as one who can be trusted and whose life is godly. The audience definitely thinks of the speaker in terms of authoritativeness (intelligence) and trustworthiness (character). The sermon must also be logical thus the premise on which the argument is based should be logical, for example,

Major premise: Jesus died for all people.

Minor premise: I am a person.

Conclusion: Jesus died for me.

Aristotle believed that the effective speaker must know how to stir up various emotions in the audience (Griffin, 2000, p. 280). In sermons, speakers would like to arouse certain feelings in the audience and, in order to do this, they need to know how to manipulate language effectively. There are speakers who are endowed with the ability to appeal to audiences emotionally better than others and such speakers achieve audience response easily. This often has to do with character and at times experience in the art of preaching. The effectiveness of a speaker can therefore not be judged based on the ability to stir up emotions as Aristotle believed because of different personality traits of people.

Loscalzo (1992, as cited in Miller, 1994) states that "the key to effective preaching is for you to remember that preaching is a dynamic event that requires you to use effectively all your skills of communication, your voice, your gestures, your personality, your spirit, your total self" (p. 191). The proper use of illustration is the key to power communication. As Sangster (1973, cited in Miller 1994) observes, "at any level of persuasion, illustration is the preacher's help. A vivid picture that clarifies thought or a 'feelingful' story touches the emotion (both in their different ways) thrust at the resisting will..." (p. 196-197). This lends credit to this paper in that preachers always strive to use vivid pictures or practical examples that have a lasting impact on the audiences. The use of relevant illustrations helps the speaker to achieve his intention of getting the desired effect from the audience. The illustrations also enable preachers to hold audience attention longer. However, there are preachers who fail to use illustrations that relate to the audiences' personal experiences and so do not make the messages practical to the audiences. Audiences in church appreciate messages that are practical and which they can apply in their situations and this is a challenge to speakers who must tailor their messages to meet the needs of varied audience members.

Imagery has been implicated as a catalyst for goal-directed action more generally: "without the guidance of images, actions would not take us far. Good actions need the company of good images" (Damasio, 1999, p. 24). If good actions, in fact, require the company of good images, then a leader's ability to "persuade people to do what they ought to do without having to be persuaded" (Truman, as cited in Miller, 1994, p. 16) may rest on his ability to convey images in words. Preaching has the ultimate aim of persuading the audience towards a certain goal and preachers do not just use 'plain' language; they also employ images by using idioms and metaphors to make their intentions known. 
Kambo (1997) adds that speech acts are important because the advertiser must communicate what he is doing by the written word such as warning, appealing, advising, challenging, thanking or promising. She, however, does not mention the use of performative verbs to perform speech acts and this gap was filled by this article which identified the performative verbs preachers make use of to perform illocutionary acts. The identification of speech acts helps the reader understand what the advertiser says. This was relevant to this article because in sermons speakers perform various acts with language which they expect the audience to identify and, in so doing, understand the sermons. Preachers express their intentions and hope to achieve the goal of influencing the behaviour of the audience.

Abbeduto, Furman and Davies (1988) conducted a study on the identification of speech acts from contextual and linguistic information. Their experiment was to examine the comprehension of interrogatives, such as 'could you make the pencil roll?' which can be intended as yes-no questions, as directives to perform an action or as both. They also wanted to identify the types of contextual information listeners use in comprehending speech acts. They observed that most utterances can be used to perform different speech acts in different contexts. They give an example of the utterance 'That's mine' and say it can be a directive to act if addressed to a child who was using the speaker's item without permission or an assertion if said by a wealthy man letting one know of the wealth he has amassed. They found that listeners follow an answer-obviousness rule, utilize their knowledge of objects and the actions they allow as context for sentence interpretation. The answer-obviousness rule captures the generalization that speakers are cooperative and only ask questions to gain information they lack, i.e., only questions that have non-obvious answers. This is relevant in the interpretation of the questions identified in the sermons analysed in this study. However, there are also questions that require mental responses and these do not necessarily follow the answer-obviousness rule. They are mainly used to challenge the audience by causing them to meditate on a certain idea or principle.

\subsection{Statement of the Problem}

The sermon as a speech event involves communication between the preacher and audience. As such, in a sermon there is understanding and sharing of meaning that takes place. The sermon is a monologue as it involves one speaker addressing many people with a view to influencing them. Therefore, the speaker may employ certain strategies to ensure audience participation. Although other studies have been carried out in the area of pulpit discourse, the speech acts in sermons have not been adequately described. This is the gap that this paper set out to seal by identifying and describing the speech acts used in sermons. The paper answers this question: What are the speech acts used by the selected preachers to convey meaning in their sermons?

\section{Materials and Methods}

The research targeted speakers and audiences in Pentecostal churches in Eldoret town, Uasin Gishu County, Kenya. Pentecostal churches refer to those in which "the central focus is the Holy Spirit and the manifestations of the spirit through speaking in tongues, healing, prophecy and discernment of spirits. They also believe in the casting out of demons, loud prayers, clapping and shouting, usually characterize their worship" (Taiwo, 2005).

The author targeted those churches that use English only or English and Kiswahili in conducting their services. The recordings were done in six churches and a total of ten sermons were collected. The researcher used purposive sampling method to sample sermons that she found relevant to the study. Five sermons were selected for data analysis and three of these were sermons preached by the pastors of the churches and two by visiting speakers who are in Christian ministry. The researcher also sought the opinion of other preachers and pastors who had interacted for a longer period with the subjects. This was to avoid bias and so establish validity and reliability of the data collected. In addition, the researcher chose these subjects because they had theological training.

The churches visited included those located 5-7 kms from the Eldoret town centre. The churches considered include Deliverance Church, Eldoret Happy Church-Town Centre, International Vision Centre (IVC), Christian Growth Centre, Sirikwa Pentecostal Fellowship-Central, and Sirikwa Pentecostal Fellowship-Mission Centre. The audiences in the churches visited ranged in number from 200 to 500 people. They consisted of youth (13-20 yrs) and adults (21-yrs and above).

The sermons were transcribed word-for-word and then typed out for analysis. The analysis was done by, first, categorizing the data into four types of speech acts using the typology developed by Bach and Harnish (1979). The categories were constantives, directives, commissives and acknowledgements. Under each category, the data was presented along the different illocutionary acts performed with appropriate texts to illustrate each act. The speech acts were interpreted using the propositions of the Speech Acts Theory. The linguistic features were identified and used in the interpretation of data. These features were taken to be the units that trigger the illocutionary acts and include: single words, phrases, clauses or whole utterances.

\section{Results and Discussion}

The research examined the speech acts used in the sermons and their role in conveying meaning. From the research 
results, the speech acts identified were categorised into: constantives, directives, commissives and acknowledgements.

\subsection{Constantives}

This section presents and discusses data on utterances that were purely informative and could be judged as true or false. These are the utterances that commit the speaker to the truth of the proposition expressed. Preachers make statements, assertions and declarations in their sermons.

\subsubsection{Reminding}

In pulpit discourse, preachers at times remind the audience about certain issues mentioned earlier or known to them. Text 1 below gives an utterance by a preacher that serves as a reminder of the topic being handled. Text 1 is an extract from a sermon based on the topic 'Seasons' and the utterance was made at the beginning of the sermon.

TEXT 1: "We've been dealing with the subject 'seasons' for some time now and a season comes with several things" +

The utterance "we've been dealing with the subject 'seasons' for some time now..." performs the illocutionary act of reminding the audience of the topic of the sermon. This interpretation is based on the meaning of the words used and the context. The verb phrase 'have been dealing' is in the present perfect continuous tense, which denotes an action that was started sometime in the past and is still going on. The use of the indefinite pronoun 'some' to show the amount of time further complements this interpretation. The use of the first person pronoun 'we' at the beginning of the utterance is an example of the use of inclusive language in pulpit discourse. It refers to the preacher and the audience and serves to bridge any gap that may be there due to the power relations that hold in pulpit discourse. It also shows that the audience, most of who are members of the church, share the context and have listened to the topic before so they interpret the utterance to mean a reminder that the topic is not over yet or is to be continued at that time. Even those visiting share the context of the utterance which is the beginning of the sermon when the topic is stated. The utterance can also be interpreted as a statement of the topic because the topic is actually given in the utterance. This is supported by the view that a single utterance can be the performance of more than one illocutionary act (Asher \& Simpson, 1994). The illocutionary act of the preacher in the above utterance is thus interpreted based on the meaning of the words used derived from the relationship that holds between the words and the context in which it was uttered.

\subsubsection{Stating}

Text 2(a) is an extract from a sermon based on applying the word of God in our lives. The context is at the beginning of the sermon, although it was not the first utterance of the speaker. The speaker had started by stating the key scripture as James 1:22 "Do not merely listen to the word and so deceive yourselves. Do what it says." This scripture encourages people to do what the word of God says. The speaker then makes the utterance and thus performs the illocutionary act of stating the topic.

Text 2(a): "This morning we want to talk about applying the word of God in our lives" +.

The adverbial phrase 'this morning' is a deictic expression referring to the time when the topic is to be handled which in the said context is the sermon time. Like in Text 1 , there is the use of the pronoun 'we' to refer to the preacher and audience in their shared context of the church service. The verb 'want' is in the simple present tense to indicate an action that is to start any time now. The phrase 'talk about' triggers the topic. The relationship that holds between the words in the utterance and the context help in the interpretation of the illocutionary act as stating the topic. Unlike in Text 1, this is a new topic because the structure does not presuppose a reminder. Generally, topics are first stated at the beginning of sermons so that the audience is aware of what is going on. Some preachers, however, do not state their topics at the beginning but make statements in the process of speaking that lead the audience in establishing the topic.

Text 2(b) is a statement on the appropriateness of the sermon and the speaker makes the statement to draw the audience's attention to her sermon. By stating all the categories in the audience that the sermon will benefit, the speaker intends to capture the attention of everybody in the audience.

2(b) There is an application from the passage for everybody - children, parents, workers, mothers, wives and women generally + .

3.1.3 Affirming

Text 3 is an extract from a sermon based on living with a difference and was said in the introductory part of the sermon. In this sermon the topic was stated later in the process of preaching. The sermon was peached at the height of the campaigns for the referendum on the constitution of Kenya which was to be held on $21^{\text {st }}$ November 2005 . The preacher thus made the utterance in order to identify with the state of affairs in the country. It was meant to create a desire in the audience to listen to the sermon. The utterance acted as a prelude to the subject of the sermon. Text 3(a): "The country is going through transition as people prepare for the referendum + Our politicians have been moving around the country drumming up support for orange or banana ++ I didn't know they were this creative...they have composed songs in praise of banana and stuff like that"

The preacher performs the illocutionary act of affirming. He affirms the state of affairs in the country which has 
existed for a while and will continue to be so until the referendum is held. The third possessive pronoun 'our' is used to refer to a third party, the politicians in Kenya, and this is interpreted to mean that since the audience and the preacher are Kenyans the politicians in Kenya are theirs. It is a way of identifying with the country and all that is in it. The state of the affairs in the country is clear to the audience and so when the preacher says '...drumming up support for the orange or banana' it is not to be taken as literally gaining support for the two fruits. The words refer to the symbols of the two opposing views on the constitution which voters are to choose for there to be a way forward. By affirming the state of affairs in the country, the preacher intended to perform the act of creating suspense in order to capture audience interest. Suspense is created because the audiences in church usually expect the speaker to start by praying, stating the topic or giving the scripture reference. None of these was done at the beginning of this sermon, so the audience members are left wondering what will come next. The speaker states his topic later in the sermon when the audience least expect it and relates it to the utterance above. The utterance is interpreted as an affirmation of the state of affairs in the country because the meaning of the words used provides information on what is happening. The context, which in this case includes the state of affairs in the country at the time of preaching, offers the audience the social information needed to understand the speech act. The contextual information goes beyond the semantic field because it is not in the utterance.

In Text 3(b) below, the speaker was talking about the need for Christians to apply God's word in their lives.

Text 3(b): It is the word of God that makes us strong Christians- it's the word of God that encourages us to encounter and confront situations in life+.

The speaker affirms the importance of God's word in order to emphasize the theme of his message to the audience. $\mathrm{He}$, therefore, prepares the audience for what is to come, which in this case are the practical ways of applying God's word in one's life.

\subsection{Directives}

This section presents data on utterances that require action on the part of the hearer. By making these utterances, the speaker tries to get the hearer to behave in some way. The illocutionary acts discussed below are warning, advising, challenging, and amusing.

3.2.1 Warning

Text 4 is an extract from a sermon based on wealth and foolishness. The speaker was talking about a man in the Bible called Nabal who was wealthy but acted foolishly. He had a wife who was beautiful and wise and this saved the situation. David is also a man in the Bible who was godly but sent some people to greet Nabal in his name and not God's name. The speaker uses these examples in the context at hand because there may be people in the audience who are rich but foolish like Nabal or who trust their own strength like David did. This is a way of making the sermon applicable to the audience's situation.

Text 4: "We notice one thing about David and I want to warn us concerning that ++ HE says in verse 5 '... and greet him in my name' + what is the problem here? + Pride + David has done exploits and is very famous in Israel ++ he missed the point when he sent the young men in his name + Amy be it would have been different if he had sent the young men in the Lord's name" +.

The preacher performs the illocutionary act of warning using the clause 'I want to warn us...' The illocutionary act is triggered by the performative verb 'warn.' In this utterance, saying 'warn' is equal to doing the act of warning. The preacher uses the example of David to warn the audience and herself included (inclusive pronoun 'us' is the object of the verb) against the danger of pride. The audience understands that as much as 'David' refers to a man in the Bible whom they have never seen, yet the warning is appropriate because the word of God should be practical in their lives. When she says 'he missed the point...', she does not literally refer to a certain mark missed but implies that David went wrong by depending on his own strength and that is why Nabal did not listen to the men he sent. What the speaker intends to convey through his utterance is that it is wrong to act in one's own strength and that when Christians act in God's name they gain victory. Acting in God's name means relying on God in whatever a Christian does. This information is not stated directly but the interpretation is arrived at based on the meaning of the words in the context of use.

Text 5 is an extract from a sermon on seasons. The preacher's aim was to cause the audience to depend on God's grace to go through the different situations in life. The utterance is used to warn the audience against taking pride in their achievements or positions. Instead, they should acknowledge God's power in all they do. The preacher made the utterance after using Paul's example of the discomfort he had to undergo so as not to take pride in his achievements.

Text 5: "Some of us take pride in our riches or achievements + God stopped Paul from exalting himself by giving him a thorn in the flesh + when God raises you to a certain place - watch out otherwise there will be a thorn that will accompany you."

The adverbial clause 'when God raises you...' implies that God will raise someone at a certain time if it has not been done yet. The word 'raise' in this context means to gain an achievement in life which could be a position of authority or wealth and the warning is meant to prepare even those who have not been raised yet. The illocutionary 
act of warning is not performed by the verb but is implied from the contextual information and the verb phrase 'watch out'. This phrase is in the imperative and is used to tell somebody to take care implying there is a danger ahead. In this context, it is used to warn the audience to take care lest they are faced with unpleasant situations like Paul because of not acknowledging God's grace. Paul refers to a Biblical character and the audience understands this because in the religious set up, characters in the Bible are used as examples to make the message applicable to the audience.

\subsubsection{Challenging}

Text 6 is an extract from the same sermon as Text 4, based on the topic wealth and foolishness. This time the preacher uses the example of Abigail, the wife to Nabal who was mentioned earlier as being wealthy but foolish. The illocutionary act is directed towards the women, especially the married women, in the audience. The context is where the preacher was talking about how Abigail acted swiftly and discreetly when her family was in danger. She knew that her husband was foolish so she didn't wait for him to act but took it upon herself and saved the family from danger.

Text 6: "I want to challenge the women here that we can be strong + Abigail was able to ride a donkey and was discreet" + .

The preacher performs the illocutionary act of challenging using the performative verb 'challenge.' By uttering the verb, she performs the act of challenging the women in the audience to rise up and be strong the way Abigail was. The speaker posed this challenge specifically to the women because, generally, in the African context, women are thought to look up to their husbands for direction on issues of security. By using the example of Abigail who had acted to save her family, she intended to challenge the women to be wise and act when situations arise that need their attention. She uses the example of a woman to appeal to the women in the audience and this is carried in the phrase '...women here.' The deictic expression 'here' means at this place so her challenge is immediate she is not referring to the women who are not in the audience but the ones there at that time.

Text 7 is an extract from a sermon based on living with a difference and it consists of rhetorical questions used by the preacher to challenge the audience towards some form of action based on the sermon.

Text 7: "A lot has been happening and the question you tend to ask yourself is 'can I make a difference in my country?' + What is it that I can do as a single Kenyan to make a difference in my country - place of work family - or school? + Do you want to live just like anybody else? Are you different or you just do things like everybody else?" +

The rhetorical questions have no performative verbs but the preacher, in uttering them, performs the illocutionary act of challenging. This is supported by the findings of the study carried out by Taiwo (2005) on the forms and functions of interrogation in Christian pulpit discourse. Rhetorical questions are generally known not to expect verbal responses and, as Taiwo (2005) observed, these questions were "mainly used to set the listener thinking and thereby having a fresh insight into an already familiar idea, principle or story. The questions elicit mental responses like a meditation on the question being asked" (p. 129). Personal observation revealed that the audiences were characterized by a meditative mood when the questions were asked showing that they were achieving their purpose. The questions cited in Text 7 are all geared towards challenging the audience to assess themselves and see whether their lives are making a difference for God. For example, 'Do you want to live just like anybody else?' implies that Christians should be seen to be different from non-Christians by the way they carry out themselves. The interpretation is based on the contextual information that the preacher's sermon was based on making a difference and he had given examples of how Christians can make a difference and also examples of how Christians fail to make a difference. Living with a difference in this context means doing one's best to please God at all times because that is the duty of a Christian and the audience understands this concept. The same words said in a different context could mean anything else.

3.2.3 Advising

Text 8 is an extract from a sermon entitled 'seasons' and based on why people need God's grace to succeed in the different situations we encounter in life. The word 'seasons' is used to refer to the different experiences people encounter in life and the audience understands it in this context. The preacher was advising the audience to ask God for more grace to succeed in life. He had just explained the benefits of experiencing God's grace in one's life and the danger of not acknowledging God's grace. Grace in this context is used to mean the favour of God or the enabling power of God upon a Christian's life. The word 'grace' is an example of religious register that is used in the church setting.

Text 8: "I want to advise you + + if there is anything you need to ask the father for - it's grace" + .

The preacher performed the illocutionary act of advising using the performative verb 'advise' and so saying is equal to doing. The personal pronoun 'I' refers to the preacher and the verb is in the present tense so as he utters the words 'I want to advise...' he is performing the action of advising. The advice is addressed directly to the audience signalled by the second person 'you', which is used in the plural form in this context. The context of the warning was appropriate because the preacher had discussed the benefits of God's grace and the dangers of not acknowledging God's grace. He had thus appealed to their emotions and prepared the ground for his intention to 
be understood. The utterance is aimed at causing the audience to strive to acknowledge God's power in their lives. 3.2.4 Amusing

Text 9 is an extract from the sermon on living with a difference and it is a story the preacher gave about his difficult past life to illustrate the fact that one cannot change his past. The story was told after the preacher had declared that God wants Christians to be different and to make a difference for him.

Text 9: "I personally come from a very poor background and I can't change that + I wore my first pair of shoes when going to high school + When I wore my first pair of slippers - I couldn't just wear them well because my big toe and the next one were so far apart - (laughter) - they didn't want to have fellowship- (more laughter)(points at his feet to demonstrate)- (great laughter)- so when I was walking- the slippers would come off and then I try to have them on again- (moves to demonstrate the walking) - (laughter)- they weren't just in fellowship + thank God for shoes + Today at least my toes are in fellowship." (Continued laughter)".

The use of stories or personal experiences is an important way of appealing to the audience emotionally. It captures the audience's attention and in this way, the preacher also makes the message practical and real. This is supported by what Loscalzo (1992, as cited in Miller, 1994) says: "preaching is a dynamic event that requires you to use effectively all your skills of communication, your voice, your gestures, your personality, your spirit, your total self" (p. 191). Similarly, Sangster (1973, as cited in Miller, 1994) says, "At any level of persuasion, illustration is the preacher's help. A vivid picture that clarifies thought or a 'feelingful' story touches the emotion..." (p. 196197).

The phrase '...my big toe and the next one were so far apart' triggers laughter immediately and as the story continues more laughter is heard from the audience. The words create a picture in the minds of the audience that causes amusement. The non-verbal behaviour of 'pointing at the feet' creates more laughter. When the preacher says '...I was walking- the slippers would come off and then I Try to have them on again', he gain demonstrates the walking (moves to demonstrate the walking), and this causes more laughter. The illocutionary act of amusing can be said to be triggered by both the words used and the non-verbal behaviour of the speaker. Norton (1983) asserts that "dramatizing relieves tension" and this is evidenced in the above text where dramatizing caused laughter which relieved tension. Laughter is an example of perlocution in this context as it is an observable response effect of the illocution on the audience. The tension can be said to have been caused by the strong appeal to the audience to lead lives that make a difference for God and not to let their past deter them from doing so. The preacher performed the illocutionary act of amusing the audience and also making the message practical. His personal example was appropriate because the audience view him as one who has made it in life and would never imagine he had gone through a difficult past. His illustration thus served to prove to the audience that in deed the pas cannot be changed but one should not dwell in the past difficulties.

\subsection{Commissives}

In this category, the utterances commit the speaker to some action at the moment or in the future. These illocutionary acts are performed for the benefit of the hearer. The action to which the utterance commits the speaker is for the benefit of the hearer. For example, in the case of a promise, it is the hearer, and not the one promising, who benefits from what is promised.

3.3.1 Inviting

Text 10 is an extract from the sermon based on seasons. It is taken from the closing section of the sermon. The preacher had finished preaching and, as a way of eliciting response to his sermon, he performed the illocutionary act of inviting the audience for prayer by making an altar call. 'Altar call' is a form of religious register which is understood in this context as the invitation for prayer for salvation or different needs based mainly on the subject of preaching. The response elicited is usually behavioural in the form of raising hands, standing or going forward depending on what the preacher asks them to do. These responses serve the purpose of identifying the audiences who respond to the needs being mentioned. They are perlocutionary acts caused by the preacher's utterances. The aim is to encourage the audience to heed the given message by applying it in their lives. The altar call is commissive because the preacher invites the audience and offers to pray for them. The speaker thus commits himself to fulfil the act of praying for those who fall in the categories mentioned.

Text 10: "You are here and you need grace to take you further -raise your hand I pray for you".

The words 'You are here and you need grace...' are addressed to anybody in the audience and serve the purpose of identifying the addressee as 'those who need grace.' The clause 'raise your hand' tells the addressee what to do and performs the illocutionary act of promising. The preacher is promising to pray for those who raise their hands. The response elicited is behavioural as seen in the raising of hands. The context is appropriate because the audience have listened to the sermon and how to apply it in their lives so they can respond appropriately. The preacher prayed for those who raised their hands to receive God's grace. This is the action that benefits the audience, the preacher promises to pray for them not for himself and he actually prays for them. The words used and the context of use bring about the interpretation of the utterance. The altar call as an illocutionary act is an invitation because the preacher invites the audience to go for prayer. 
Text 11 is an extract from the sermon based on living with a difference and is also taken from the closing part of the sermon. It is an invitation for people with different needs to raise up their hands and be prayed for.

Text 11: (Prays to close session) "In that mood of prayer- you are here listening and may be you feel like you'd like to make a difference wherever the Lord has placed you but you just feel like something has held you back ++ and this morning you want to cast away that and make a difference - I wanna pray with you right now + If you are that person just raise your hand + (hands are raised) May be you are here and you've never given you're life to the Lord- I want you to know that you'll never make a difference unless you become different + It all starts by being different + This morning you want to give your life to the Lord + + just raise your hand and I'll pray with you + + (no hands raised) You have a need and you need prayer, raise your hand." (hands are raised).

The speaker uses the phrase 'in that mood of prayer' which in the church context is understood as a way of making an altar call. It is a religious register which means in that state of prayer and prepares the audience for the categories of people being invited for prayer. Its meaning is thus restricted to the religious setting. The speaker uses the clause '.... and this morning you want to cast away that and make a difference' to perform the act of identifying the category of people he is addressing. This altar call is geared towards causing the audience to apply the message to their lives. It is commissive in that the speaker is expected to perform the action he mentions at that time for the benefit of the addressee. The speaker is inviting the audience for prayer by making the altar call. The illocutionary acts of inviting and promising are performed in the clauses such as '...just raise your hand' and 'I'll pray with you,' respectively. It is noticeable that in each case the preacher elicits a behavioural response in the way of raising hands and this is supported by the findings of Taiwo's (2005) study on response elicitation in English medium pulpit discourse. In each case the speaker performs the act of identifying the category of people being invited for prayer. This can be explained by the fact that people have different needs to be addressed when they go to church.

\subsection{Acknowledgements}

This category deals with utterances that express the speaker's psychological attitude towards a state of affairs which the illocution presupposes. The speaker makes an utterance that expresses his feelings towards what has happened as presupposed in the utterance.

3.4.1 Thanking

Text 12 is an extract from the sermon based on authentic devotion and is taken form the introductory part of the sermon. The speaker is acknowledging the financial assistance given to him by the church. The speaker is a member of the church who works as a missionary in a different country and the church sends financial assistance from time to time.

Text 12: "I want to take this early opportunity to thank you as a body of believers who deeply honour the gospel of God and move it forward the way you have done through us.".

The illocution presupposes that the preacher has received help from the church and he is performing the illocutionary act of thanking them. The presupposition is contained in the clause '....as a body of believers who deeply honour the gospel of God and move it forward the way you have done through us.' The phrase 'body of believers' is restricted to the religious context and refers to Christians and in this case the members of the church where the preacher is presenting the sermon. The illocutionary act is performed by the verb 'thank.' The preacher uses the words 'move it forward' to mean that the financial assistance given to him enables him to sustain his family and preach the gospel so that it spreads.

3.4.2 Greeting

Text 13 is an extract from the introductory part of a sermon and the preacher's intention is to greet the audience. Greeting is an acknowledgement since it is a way of showing that the preacher has noticed or recognized the audience. The presupposition is that he is meeting the audience for the first time that day.

Text 13: "I greet you in Jesus' name + Praise the Lord" (Amen).

The preacher was meeting the audience for the first time that day and started by greeting the audience. He performs the illocutionary act of greeting using the verb 'greet.' He also uses the phrase 'praise the Lord' to elicit response in the form of a conventional answer, as asserted by Taiwo (2005). This clause is also used as a form of greeting among Christians even outside church and it elicits the verbal response 'Amen' which means 'let it be so.'

\section{Conclusion}

The aim of this paper was to establish the speech acts used as communicative acts in pulpit discourse, which is mainly a monologue. From the results, it was shown that preachers perform different speech acts using different clause types. These speech acts were categorised into constantives, directives, commissives and acknowledgements.

Constantives comprise utterances that commit the speaker to the truth of the proposition and cannot be judged as true or false. The illocutionary acts observed among preachers included reminding, stating, affirming and capturing audience interest. Directives comprise utterances in which the preacher's intention is to elicit some action 
from the audience. The illocutionary acts are performed using performative verbs, phrases and rhetorical questions. The findings here show that preachers warn, advice, challenge and amuse the audience through their utterances and actions. The illocutionary acts performed in the category of commissives are for the benefit of the audience and are promising and inviting. Religious register such as 'in that mood of prayer' is used to perform the illocutionary act. The preachers use clauses like 'you are here and you need...' to identify the people they are addressing since people have different needs. The category of acknowledgements shows that preachers perform illocutionary acts of thanking and greeting. These acts are performed using the verbs 'thank,' 'greet,' and also the conventional formula 'Praise the Lord.' These acts express the preacher's psychological attitude towards a state of affairs presupposed by the illocution.

It is recommended that future investigations should focus on the use of idioms in sermons to examine their relevance for communication. This paper analysed sermons from Pentecostal churches in town only and we recommend that the same concepts be analysed in sermons from Pentecostal churches in the rural area.

\section{References}

Abbeduto, L., Furman, L., \& Davies, B. (1988). Identifying Speech Acts from Contextual and Linguistic information. Language and Speech. 32, 189-203.

Asher, R. E., \& Simpson, J. M. Y. (Eds) (1994). The Encyclopedia of Language and Linguistics. Vols. 4, 6, 7 and 8. England: Pergamnon Press Limited.

Bach, K., \& Harnish, R. M. (1979). Linguistic Communication and Speech Acts. Cambridge, Mass: MIT Press.

Brown, G. (1995). Speakers, Listeners and Communication: Explorations in Discourse Analysis. Cambridge: Cambridge University Press.

Damasio, A. R. (1999). The Feeling of What Happens. New York: Harcourt Brace.

Griffin, E. (2000). A First Look at Communication Theory ( $4^{\text {th }}$ ed.). New York: McGraw-Hill Companies, Inc.

Kambo, R. N. (1997). An Analysis of Presuppositions, Speech Acts, Implicatures and Socio-ideological Values in Written Advertisements (Unpublished M.Phil. Thesis). Moi University.

Miller, C. (1994). The Empowered Communicator: Keys to Unlocking an audience. Tennessee: Broadman and Holman Publishers.

Norton, R. (1983). Communicator Style: Theory, Applications and Measures. California: Sage Publications, Inc.

Pearson, J. C., \& Nelson, P. E. (1994). Understanding and Sharing: An Introduction to Speech Communication. Iowa: Wm. C. Brown Communications, Inc.

Taiwo, R. (2005). Forms and Functions of Interrogation in Christian Pulpit Discourse. Nebula. 2(4), 117-131.

Trenholm, S. (2001). Thinking through Communication: An Introduction to the Study of Human Communication ( $3^{\text {rd }}$ ed.). New York: Allyn and Bacon. 